\title{
Traffic air emission inventory and measures to reduce air pollution in Ho Chi Minh City, Vietnam
}

\section{Quoc Bang $\mathrm{Ho}^{\mathrm{a}}$, Hoang Ngoc Khue Vua , Thoai Tam Nguyena, Thi Thuy Hang Nguyen ${ }^{\mathrm{a}}$}

\author{
a Institute of Environment \& Resources, Vietnam National University, Ho Chi Minh City, Vietnam \\ Email:vhnk1304@gmail.com; thoaitam1986@gmail.com; hangnguyen6769@gmail.com.
}

Received: 08 June 2019 / Revised: 12 December 2019 / Accepted: 18 February 2020

\begin{abstract}
Together with the urbanization, industrial activities are increasing and transportation system is being rapidly developing. In 2017 , the population of Ho Chi Min city (HCMC) is over 8.6 million. The city has 8 million vehicles including 637,323 automobiles and more than $7,339,522$ motorcycles. Up to now, the city has a total of 2708 factories generating air emissions (including 3 processing zones (EPZs) and 16 industrial parks (IPs), with thousands of factories outside the IPs / EPZs), resulting in an increase in emissions from these activities and affecting the air quality of the city. Therefore, in this study (i) collect air emission data, evaluate and calculate of air emissions by applying EMISENS emission calculation models and survey and traffic counting methods; (ii) Develop clean air action plan and climate change mitigation for Ho Chi Minh City. The results showed that on-road activities are the major contributor, accounting for $88 \%$ of $\mathrm{NOx}, 99 \%$ of $\mathrm{CO}, 79 \%$ of $\mathrm{SO}_{2}, 99 \%$ of $\mathrm{NMVOC}, 88 \%$ of $\mathrm{PM}$ in total emissions from transportation activities. Key finding in this study is that harbour activities contribute up to $20 \%$ of total SOx and $10 \%$ of total PM. Other sources (airport, harbour, bus station, rail way) only accounting for negligible amount of emissions. Emission maps showed that emissions in harbours and in central areas of the city as District 1, district 10, district 3 and district 5 are higher than the other districts. This study has also developed 13 measures to effectively manage air quality and reduce GHG in Ho Chi Minh City.
\end{abstract}

\section{Keywords:}

Air Pollution; Traffic, air emission; Ho Chi Minh City; Measures.

(c) Euraass 2020. All rights reserved.

\section{Introduction}

Air pollution is now a worrying issue for health. The large cities in the world are confronting with air pollution, and the main emission source from traffic activities. This emission source of London accounted for 50\% (for NOx and PM) (London Council, 2018), Bangkok city

*Corresponding author: E-mail: bangquoc@yahoo.com (QB Ho), Ph: 0906834630

Available online: $30^{\text {th }}$ March 2020

DOI: https://doi.org/10.34154/2020-JUE-0101-29-38/euraass

Journal reference: J. Urban Env. 2020, 01(01), 29 - 38.

ISSN-E: 2726-0844.

(C) European Academy of Applied and Social Sciences. Euraass - 2020. All rights reserved.

Cite as: Ho, Q. B., Vu, H. N. K., Nguyen, T. T., \& Nguyen, T. T. H. (2020). Traffic air emission inventory and measures to reduce air pollution in Ho Chi Minh City, Vietnam. J. Urban Env. 01(01), 29-38. 
was more than $60 \%$ (for substances except for $\mathrm{SO}_{2}$ ) (Supat, 2013), Madrid was 39\% $\left(\mathrm{PM}_{2.5}\right)$ and Paris was $29 \%\left(\mathrm{PM}_{2.5}\right)(\mathrm{European}$ Commission, 2017). HCM city has the highest number of vehicles in Vietnam with a total of 8 million active vehicles in April 2017, of which cars were 637,323 motorbikes were 7,33,5,522 vehicles (Excluding vehicles from other immigrants, an increase of $5.4 \%$ compared to 2016 (HCMC DOC, 2017). The number of vehicles is increasing, HCMC confront with an increase in air pollution levels. With AQI data many days in the year reaches high value. According to the statistics of GreenID, the annual average $\mathrm{PM}_{2.5}$ concentrations of $\mathrm{HCMC}$ was $29.6 \mu \mathrm{g} / \mathrm{m}^{3}$ in 2017 (Nguyen et al., 2018) higher than the Vietnamese standard QCVN 05: 2013/BTNMT (25 $\left.\mu \mathrm{g} / \mathrm{m}^{3}\right)$ and many times higher than WHO standards $\left(10 \mu \mathrm{g} / \mathrm{m}^{3}\right)$. In 2017, the number of days the city had $\mathrm{PM}_{2.5}$ concentrations higher than the WHO's standard $\left(25 \mu \mathrm{g} / \mathrm{m}^{3}\right.$ 24-hour) was 222 days and exceeded the Vietnamese standard (50 $\mathrm{\mu g} / \mathrm{m}^{3}$ 24-hour) was 4 days (Nguyen et al., 2018), it directly affects to people's health.

Inventory of emissions is an indispensable step in the task of air quality management. Advanced countries inventoried emission for their cities and the European is implementing $\mathrm{PM}_{2.5}$ map for the whole region. In Vietnam, the emission inventory has been carried out for Bac Ninh and Can Tho cities with the support of the German Development Cooperation (GIZ) and Clean Air Asia (Clean Air Asia). These studies have carried out a comprehensive emission inventory for the city including transport, industrial and household ...

In this study including: i) To develop a database on air emission in Ho Chi Minh City for efficient air quality management and determine air receiving zones for Ho Chi Minh City; (ii) To develop of a Clean Air Action plan and reducing Greenhouse gases (GHG) for HCMC.

\section{Methodology and material}

Transport in this research include: on-road source emission from vehicles (motorcycles, cars) and non-road source are harbours, airway (the activity of aircraft), railway (the activity of train), and emission from bus stations. These are typical pollution of city.

Calculating emissions for these activities, we need to collect raw data and then aggregate. And emission inventory is using the model method and the emission factor method. After having emission data, we distributed emission according to space using ArcGIS software. The pollutions are $\mathrm{CO}$, and $\mathrm{NMVOC}$, and $\mathrm{NOx}$, and $\mathrm{SO}_{2}$ and TSP.

\subsection{Sea port}

For seaport, carry out a survey on the anchoring of vessels and cargo-handling equipment at Saigon Port system, and emission inventory using the formula of US.EPA guidelines for port operations.

Ocean going vesels (OGVs):

$$
E=P \times L F \times A \times E F
$$

Cargo-handling equipment (CHE):

$$
\begin{aligned}
& E=N \times P \times L F \times A \times E F \\
& L F=(A S / M S)^{3}
\end{aligned}
$$

Where: LF: Load factor (\%); AS: Actual speed(knots); MS: Maximum speed (knots); E: Emissions (g); N: Number of items; P: Maximum continuous power rating (kW); A: Activity (hour); EF: Emission factor (g/Wh);

\subsection{Bus station}

For bus station, HCMC has 8 large bus stations: Mien Dong bus station, Mien Tay bus station, Cu Chi bus station, Ben Thanh bus station, bus station in District 8, Cho Lon bus station, Nga Tu Ga bus station, An Suong bus station. Emissions due to this activity often overlooked in emissions inventory, but this is also an interesting source of emissions, especially for local emissions. Collecting information on the number of vehicles in a year for each bus station, and at the same time we survey the driver's behaviour of drivers to fuel consumption during the waiting process for passengers and idling berth (not including emissions due to vehicles traveling on the road). The equation for emission from bus station is shown:

$$
E=(A \times E F) / 10^{6}
$$

Where: E: Emissions (ton/year), A: Fuel consumption (kg/year) calculated according to the number of trip per year and consumption per trip, EF: là Emission factor ( $\mathrm{g} / \mathrm{kg}$ fuel) in Table 1. 
Table 1: Emission factors for vehicle in bus station and train.

\begin{tabular}{cccccc}
\hline Pollution & NOx & CO & MNVOC & PM & $\mathrm{SO}_{2}$ \\
\hline Bus station* $(\mathrm{g} / \mathrm{kg})$ & 33.37 & 7.58 & 1.92 & 0.94 & 0.5 \\
Railway ${ }^{* *}(\mathrm{~kg} / \mathrm{ton})$ & 63 & 18 & 4.8 & 1.8 & 0.01 \\
\hline $\begin{array}{l}\text { *EMEP / EEA emissions guidelines for 2013, Section 1.A.3.b, Tables 3-5 and Table 3-6. } \\
\text { ** EMEP / EEA emissions guidelines for 2013, Section 1.A.3.c, Tables 3-2. }\end{array}$
\end{tabular}

\subsection{Air way}

The number of flights for each aircraft category is collected by 2017 for all national airlines and international airlines. Emission factor is collected in inventory flight operation guidelines of ICAO (International Civil Aviation Organization). The equation for emission is shown below:

$$
E=(L T O \times E F) / 1000
$$

Where E: Emissions (ton/year), LTO: Number of flight per year (for each aircraft category), EF: Emission factor (kg/flight) in Table 2.

Table 2: Emission factor for aircraft category (kg/flight).

\begin{tabular}{lccccc}
\hline \multicolumn{1}{c}{ Aircraft } & $\mathrm{NOx}$ & $\mathrm{SO}_{2}$ & $\mathrm{CO}$ & $\mathrm{NMVOC}$ & $\mathrm{TSP}$ \\
\hline Airbus A318 & 6.71 & 0.6 & 10 & 2.0 & 0.06 \\
ATR72 & 2.34 & 0.2 & 2 & 0.0 & 0.00 \\
Boeing B787 & 17.15 & 1.3 & 15 & 0.5 & 0.09 \\
MD-11 & 38.17 & 2.2 & 18 & 1.4 & 0.17 \\
B77W & 69.79 & 2.6 & 48 & 5.1 & 0.21 \\
B788 & 17.15 & 1.3 & 15 & 0.5 & 0.09 \\
$\ldots$ & $\ldots$ & $\ldots$ & $\ldots$ & $\ldots$ & $\ldots$ \\
\hline
\end{tabular}

Source: 1.A.3.a CORINAIR for airway and ICAO, 2011: Airport Air Quality Manual, Table B-1

\subsection{Road traffic}

With road traffic, the research team has carried out a traffic inventory for Ho Chi Minh City since 2010, and so far this data is no longer relevant to the city's traffic situation. Therefore, it is necessary to update the current status of new emissions. Counting vehicles at 92 routes in the city area, for 5 main road types are main urban roads (connecting districts), sub-urban roads (connecting wards and roads in residential areas), provincial highway (connecting provinces) and national highways (including highways and existing National highways). To effectuate the new survey and re-survey of available routes to update data. At the same time, we conduct random surveys of behaviour of vehicle users (for 5 vehicles category are motorcycles, cars, light trucks, heavy trucks and bus) to know the information on vehicle life, vehicle usage frequency in the day and average length of vehicle that the vehicle operation. From the collected data, we analyse the flow for each type of vehicle for 5 types of roads as well as the vehicle technology being used in Ho Chi Minh City according to Euro standards on engine emissions.

There is a basis to set the emission factor set for the vehicle categories are close to the current state of the vehicle system currently circulating in the city road. EMISENS model was applied to conduct air emission inventory for transportation sector, was developed in 2006 - 2010 by Prof. Dr Clappier và Assoc. Prof. Dr. Ho Quoc Bang in Laboratory of Air Pollution and Soil-EPFL, Switzerland. EMISENS uses emission inventory theory from CORINAIR (EEA), it allows shortening of calculation time and error calculated by Monte Carlo simulation technique. The EMISENS model is selected because this model was developed for emission inventory from road traffic and it applies to developing countries (where data conditions are inadequate by combining bottom-up methods and top-down methods) with 
conditions like Vietnam (Bang et al., 2010). Input data of the EMISENS model requests: number of each vehicles category, length of each road type, flow of each vehicles category as of each road type, emission factor is calculated according to the vehicle system in circulation, Emission inventory for road traffic by EMISENS model is classified into 3 types of emissions: hot emissions (Ehot), cold emissions (Ecold) and evaporation emissions (Eevap)according to the equation is shown below:

$$
E_{\text {Total }}=E_{\text {Cold }}+E_{\text {Hot }}+E_{\text {Evap }}
$$

Where: $E_{\text {hot }}$ hot emissions, $E_{\text {cold: }}$ cold emissions, $E_{\text {evap: }}$ evaporation emissions

Each emission category follows a general equation in EMISENS is shown below:

$E_{i p}, i e=e_{i p}, i e \times A_{i e}$

In which E: total emission; ip: pollution i; ie: vehicle category; e: emission factor in Table 3; A: Activity rate.

\begin{tabular}{|c|c|c|c|c|c|}
\hline & NOx & $\mathrm{CO}$ & $\mathrm{SO}_{2}$ & $\mathrm{CH}_{4}$ & PM10 \\
\hline Heavy trucks & 19,7 & 11,10 & 1,86 & 0,17 & 0,13 \\
\hline Light trucks & 1.90 & 34,80 & 0,18 & 0,40 & 0,045 \\
\hline Bus & 19,7 & 11,10 & 0,18 & 0,12 & 0,178 \\
\hline Cars & 1,90 & 34,80 & 0,18 & 0,40 & 0,016 \\
\hline Motorcycles & 0,05 & 21,85 & 0,03 & 0,20 & 0,0088 \\
\hline
\end{tabular}

(Source: a) Ho et al., 2010; b) China (DOSTE, 2001); c) Calculated from CORINAIR 1999).

\subsection{Railway}

For railway, Ho Chi Minh City has Hoa Hung Station which is the final terminal of the North-South railway. The team collects and surveys the number of annual trains and interviewing the driver about the fuel consumption, the length of the railway section that the train travels in HCMC. The equation for emission from railway is shown below:

$$
E=(A \times E F) / 10^{3}
$$

Trong đó: E: Emissions (ton/year), A: fuel consumption (ton/year), EF: Emission factor (kg/ton fuel).

\section{Investigation and the survey for collecting data}

In this study, the team conducted an additional survey of 1,099 questionnaires on the status of vehicle use, and calculated based on the data for 2,924 questionnaires surveyed from 2010 up to now. According to statistics, Motorcycles on roads with engines respond to Euro 3 emissions standards are $24 \%$ and Euro 2 standards are $63 \%$, the rest are those with Euro 1 standard of $10 \%$. For cars, most of them are respond to Euro 4 emission standards with 75\%, and Euro 3 and Euro 5 with each accounting for about $10 \%$. Most trucks and buses (diesel-powered vehicles) are circulating with Euro 2 emissions standards of more than 50\%, the rest are Euro 3 and Euro 1. The study also counted cars of 92 city routes for representative roads. Proceeding manual vehicles counting method from 6 am to 19 pm and combined with 24-hour camera rotation to establish vehicle load curve for each route category. According to the survey results, motorcycles have the highest number of vehicles on the roads with the highest average load of 14,000 motorcycles, accounting for $80 \%$ of vehicles 10 times higher than the number of cars). Only $10 \%$ are cars and $10 \%$ for the remaining vehicles, the time of high traffic is from 6 am to $18 \mathrm{pm}$, especially heavy trucks operating in residential areas have peaked at night.

In addition, this study also collects air emission inventory for point source and area sources. Results are presented in the next section. 


\section{Results and discussion}

\subsection{For total sources}

- Traffic is main contribute to air pollution in $\mathrm{HCMC}$, responsible for more than: $99 \%$ of total $\mathrm{CO}, 97 \% \mathrm{NMVOC}, 94 \% \mathrm{NO}_{x}, 81 \% \mathrm{SO}_{2}$, $48 \%$ TSP and $64 \% \mathrm{CH}_{4}$ (in Table 4) Industrial source contributes a small amount of pollutants ( $19 \%$ in total $\mathrm{SO}_{2}$ and $19 \%$ of TSP)

- Area sources (including households, harbor and construction) contribute $30 \%$ emission of TSP

- Biogenic responsible for $32 \%$ emission of $\mathrm{CH}_{4}$

\subsection{Only for traffic source}

Emissions due to traffic source in the city are generally ample because HCMC has many types of traffic as airway, seaport, bus station, railway and road traffic. However, road traffic is still the main source of high density and the main emission source of the city. Emissions from road traffic accounted for $88 \%$ of $\mathrm{NOx}, 99 \% \mathrm{CO}, 79 \% \mathrm{SO}_{2}, 99 \%$ of NMVOC, $88 \%$ of TSP compared to the total traffic emissions in HCMC (Figure 1). Meanwhile transportation source (line source) play an important part in emitting a significant amount of pollutants compared to the other sources, except for TSP emissions (Figure 2).

\begin{tabular}{|c|c|c|c|}
\hline \multicolumn{2}{|c|}{$\mathrm{NO}_{\mathrm{x}}$} & \multicolumn{2}{|c|}{$\mathrm{CO}$} \\
\hline Motorcycles & $27,9 \%$ & Motorcycles & $90 \%$ \\
\hline Cars & $21,5 \%$ & Cars & 5.7 \\
\hline Harbour & $11,5 \%$ & Light trucks & 2.6 \\
\hline Light trucks & $10,6 \%$ & & \\
\hline Heavy trucks & $9,0 \%$ & & \\
\hline \multicolumn{2}{|c|}{ NMVOC } & \multicolumn{2}{|c|}{ TSP } \\
\hline Motorcycles & $68 \%$ & $\begin{array}{l}\text { Brake wear and road } \\
\text { surfaces }\end{array}$ & 36,5 \\
\hline Cars & 14 & Households & $11,0 \%$ \\
\hline Light trucks & $6 \%$ & Construction sites & $8,8 \%$ \\
\hline \multirow[t]{2}{*}{ Bus and heavy trucks } & $5 \%$ & Harbour & $7,8 \%$ \\
\hline & & Building materials vendors & $7,6 \%$ \\
\hline \multicolumn{2}{|c|}{$\mathrm{SO}_{2}$} & \multicolumn{2}{|c|}{$\mathrm{CH}_{4}$} \\
\hline Motorcycles & $35,5 \%$ & Motorcycles & $63 \%$ \\
\hline Harbour & $23,7 \%$ & Biogenic & $32 \%$ \\
\hline Cars & $9,6 \%$ & Households & $2 \%$ \\
\hline $\begin{array}{l}\text { Textile industry and heavy } \\
\text { trucks }\end{array}$ & $5,6 \%$ & & \\
\hline Food processing & $3 \%$ & & \\
\hline Paper and electricity plant & $2 \%$ & & \\
\hline
\end{tabular}




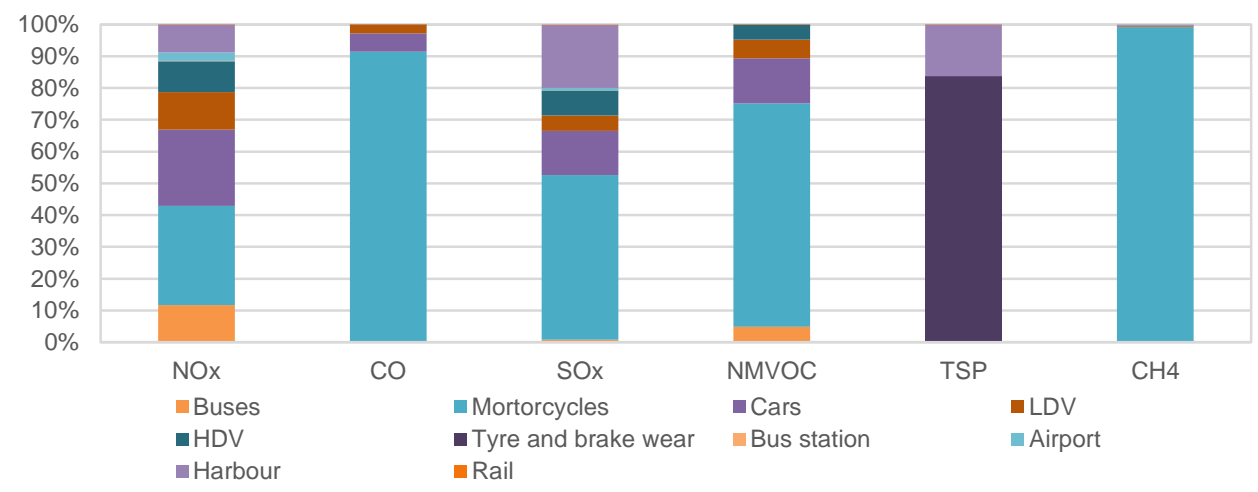

Figure 1: Shares of the emission sources.

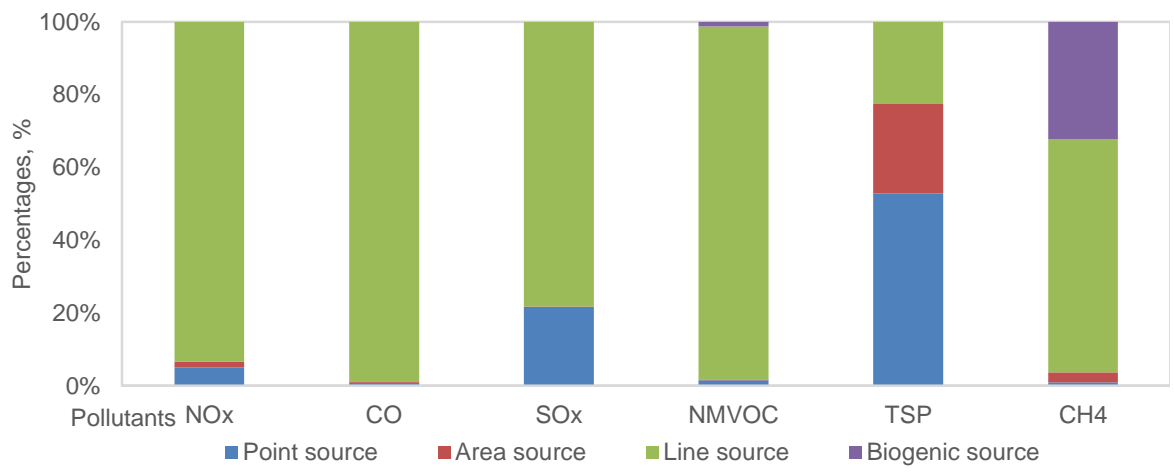

Figure 2: Contribution of transportation sources in total emissions of HCMC, 2017.

\subsection{Clean Air Action Plan}

Table 5. Air pollution control solutions in 2019-2025.

\begin{tabular}{|c|c|c|c|c|c|}
\hline No. & $\begin{array}{l}\text { Name of } \\
\text { task/project }\end{array}$ & Content & Time & $\begin{array}{l}\text { Host/ } \\
\text { Coordinate } \\
\text { agency }\end{array}$ & $\begin{array}{l}\text { budget } \\
\text { (USD) }\end{array}$ \\
\hline 1 & $\begin{array}{l}\text { Air smoke checking } \\
\text { automobile } \\
\text { randomly on road }\end{array}$ & $\begin{array}{l}\text { Establishment of "Motor } \\
\text { Vehicle Inspection Working } \\
\text { Group" (VITF) includes } \\
\text { representatives from the } \\
\text { Department of Transportation } \\
\text { (DOT), Vietnam Register } \\
\text { (VR), HCMC People's } \\
\text { Committee, and traffic police. }\end{array}$ & 2019 & $\begin{array}{l}\text { Host agency: } \\
\text { DOT } \\
\text { Coordinate } \\
\text { agency: VR- } \\
\text { DOT, Ho Chi } \\
\text { Minh } \\
\text { Environment } \\
\text { Protection } \\
\text { Agency (HEPA), }\end{array}$ & 20,000 \\
\hline
\end{tabular}


- Develop and agree on the content of "Terms of

Reference (ToR) for VITF

- Air smoke checking

automobile randomly on road

- Note: HCMC has checked a

few days for buses: As a

result, $22 \%$ of the buses were

checked for air smoke exceed

the allowable standard. It is

necessary to carry out both

random and continuous

exercises with all of the cars

- Using Motor Vehicle Inspection Working Group" (VITF)

- Develop a plan to check motorcycle exhaust emissions in circulation.

Air smoke checking for motorcycles
- Air smoke checking for motorcycles

Note: HCMC has measured in several of motorcycles: As a result, the emission from motorcycles will be reduce $30 \%$.
Host agency:

DOT

Coordinate agency: VR-

DOT, HEPA,

Traffic police

and consultants
- Reviewing and assess the short-term financial support needed to establish new bus teams and routes;

- DOT will draft the necessary

3

Develop project for public transportation

\section{regulations to facilitate the} financial support for new routes;

- New regulations approved by the HCMC People's Committee;

- Implementation and inspection;

- Developing a plan to expand the bus network.
DOT.

2019

Vietnamese

experts, 40,000

international

experts
- DOT established "Transport reorganization working group" (RTTTF). The working group will start with the signing of a

$4 \quad$ Bike sharing system Cooperation Agreement (MoU) between RTTTF members;

- Preparing ToR for the Working Group.

- Determining the role of NMT in the future

\section{DOT}

Pilot

implementation

2021- in District 1,

2022

District 3,

Vietnamese

experts,

international

experts support

technical 
- Determining the goals of the

guidance

NMT Action Plan

- Evaluating achievements.

Note: Piloting the central area of

$\mathrm{HCMC}$

- Investigate and review statistics on the number of motorcycles,

5 three-wheeled motorcycles, four-wheelers transporting passengers and goods; DOT
Vietnamese Inspection outdate remove

○ Developing regulations to suspend the vehicles have not warranted technical safety

$2021-$

2022 experts, international 250,000 experts support technical guidance.

- Using data from emissions inventories estimates potential emission mitigation, and the corresponding cost

- Experts drafted an assessment of the potential for emissions reduction using the experience Replace cleaner and cook stove for households of smaller cities in Vietnam;

- Encouraging organizations and donors to provide cleaner stoves for low-income households. Goals: 200 cleaner stoves for each district or 1000 cleaner stoves for 5 districts in the city (Binh Chanh, Hoc Mon, Cu Chi, Nha Be, Can Gio).

$\begin{array}{ll} & \text { Department of } \\ & \text { Agriculture and } \\ & \text { Rural } \\ & \text { Development } \\ 2022- & \text { (DARD), } \\ 2024 \quad & \text { Department of } \\ & \text { Natural } \\ & \text { Resources and } \\ & \text { Environment } \\ & \text { (DONRE),CFA }\end{array}$

Note: Suburban area of HCMC

- Overall assessment of fuel burning operations using boiler in Industry HCMC (5 billion dong)

Study boilers using

7 in industry and fuel

- Supporting the plant in the efficient operation of the boiler burning (reducing emissions) and 2019- DONRE, HEPA, 2024 CEM, Institutes 650,000 continuing to support the technical consultancy of the expert group 2019-2024 (2 billion dong/year)

Provide smoke checking equipment for DONRE inspection
- Equipping chimney automatic measurement equipment for DONRE to regularly as well as irregular inspection of industrial sources
2019- DONRE, HEPA, 2022 CEM 
- Strengthening inspection for establishments that have not complied with the emission regulations.

Note: Currently, the city has 812 factories, of which 764 factories (94\%) have treatment systems; 48 factories $(6 \%)$ do not have a treatment system on air pollution
- Developing communication strategies and other activities

- Hiring consultants

- Developing and implement strategies
2016- DONRE, HEPA, 2020 CEM 20172018: 2 stations 2018DONRE, CEM, HEPA

$5,470,000$

2022: 7

stations
- Every year, selection and monitoring of hot spots on air pollution; passive monitoring 1 month/point. Season; Monitoring 2 seasons/year. To enough assessment data according to QCVN 05:2013
2018- DONRE, CEM, 2022 HEPA
500,000

monitoring lab

\begin{tabular}{|c|c|c|c|c|c|c|}
\hline 12 & $\begin{array}{l}\text { Re-El every } 5 \\
\text { years }\end{array}$ & o & $\begin{array}{l}\text { Every } 5 \text { years, update the } \\
\text { emissions inventory of } \mathrm{HCMC}\end{array}$ & 2022 & $\begin{array}{l}\text { DONRE, HEPA, } \\
\text { CEM, Institutes }\end{array}$ & 75,000 \\
\hline 13 & $\begin{array}{l}\text { Study air emission } \\
\text { receiving zone }\end{array}$ & $\circ$ & $\begin{array}{l}\text { Mapping of the air pollution } \\
\text { reception area for HCMC. } \\
\text { serving as a basis for the city's } \\
\text { socio-economic development } \\
\text { planning }\end{array}$ & 2020 & $\begin{array}{l}\text { DONRE, DOST, } \\
\text { HEPA, CEM, } \\
\text { Institutes }\end{array}$ & 150,000 \\
\hline
\end{tabular}

\section{Conclusion}

Air in Ho Chi Minh city is polluted. This research developed a database on air emission in Ho Chi Minh City for efficient air quality management and developed of a Clean Air Action plan and reducing Greenhouse gases (GHG) for HCMC. In this research we did an detail air emission inventory for traffic sources. EMISENS model is applied to calculate road traffic emission. For other traffic sources, we used the emission factor method to calculate air emission. After having emission data, we distributed emission according to space using ArcGIS software. Traffic is main source contribute to air pollution in HCMC, responsible for more than: $99 \%$ of total CO, $97 \%$ NMVOC, $94 \% \mathrm{NO}_{x}, 81 \% \mathrm{SO}_{2}, 48 \% \mathrm{TSP}$ and $64 \% \mathrm{CH}_{4}$. Key finding in this study is that hahour activities contribute up to $20 \%$ of total SOx and $10 \%$ of total PM. Other sources (airport, habour, bus station, rail way) only accounting for negligible amount of emissions. Emission maps showed that emissions in harbors and in central areas of the city as District 1, district 10, district 3 and district 5 are higher than the other districts. Air quality in HCMC is polluted by O3, TSP, NOx. The research also developed 13 measures for Air pollution and climate change 
mitigation to sustainably development 2019 - 2024 is developed as follow: Air smoke checking automobile randomly on road; Air smoke checking for motorcycles; Develop project for public transportation; Bike sharing system; Inspection outdate motorcycles and remove; Replace cleaner and cook stove for households; Study boilers using in industry and fuel burning; Provide smoke checking equipment for DONRE inspection; Public raise aware on air pollution ; Air quality monitoring automatically system: 9 stations; Invest for air quality monitoring lab; Re-El every 5 years; Study air emission receiving zone map. With total cost 184,97 billion VND (9,2 mil USD).

\section{Acknowledgment}

This research work is funded by Vietnam National University Ho Chi Minh City (VNU-HCM) under grant number B2019-24-01.

\section{References}

Air Quality Atlas for Europe: mapping the sources of fine particulate matter, accessed 12/2018. https://ec.europa.eu/jrc/en/news/airquality-atlas-europe-mapping-sources-fine-particulate-matter

Air Quality Management: Thailand's Experiences. Supat Wangwongwatana, 2013. https://www.iges.or.jp/isap/2013/PDF/L1/ISAP L1 4 Supat.pdf

Airport Air Quality Manual, 2011. International Civil Aviation Organization. ISBN 978-92-9231-862-8. https://www.icao.int/publications/Documents/9889 cons_en.pdf

Demystifying Air Pollution in London Report, Condon Councils, Januray, 2018. https://www.londoncouncils.gov.uk/sites/default/files/Policy\%20themes/Environment/Demystifying\%20air\%20pollution\%20in\%20Lon don\%20FINAL\%20FULL\%20REPORT_IM_0.pdf

Department of Transport, Ho Chi Minh City, 2017. Scientific conference "Controlling the demand for using personal vehicles in Ho Chi Minh City - situation and solutions" on April 20, 2017. http://congan.com.vn/giao-thong-24h/tp-hcm-ban-cach-han-che-xe-mayphuong-tien-ca-nhan_37514.html

DOSTE (Department of Science, Technology and Environment of Ho Chi Minh city). Urban transport energy demand and emission analysis - Case study of HCM city $\mathrm{N}^{\circ} 1$ (phase II). 2001.

EMEP/EEA air pollutant emission inventory guidebook 2013. Technical guidance to prepare national emission inventories. EEA Technical report. No 12/2013. ISBN 978-92-9213-403-7ISSN 1725-2237doi:10.2800/92722.

Ho Minh Dung, Dinh xuan Thang, 2010. Study on developing a pollutant emission factor from road vehicles suitable to the conditions of Ho Chi Minh City. Sci. Tech. Dev. J. - Nat. Sci., vol. 13 of M2 - 2010; 2010. p. 5-18

Ho, B. Q., \& Clappier, A. (2011). Road traffic emission inventory for air quality modelling and to evaluate the abatement strategies: A case of Ho Chi Minh City, Vietnam. Atmospheric environment, 45(21), 3584-3593.

Nguyen Thi Anh Thu, Lars Blume, 2018. Air quality report, Air quality in Vietnam in 2017. Green Innovation and Development Centre (GreenID), Hanoi, Vietnam, April 2018. http://en.greenidvietnam.org.vn/view-document/5af836ca5cd7e87c49ee7e52 